\title{
ROAD ECOLOGY STUDIES FOR MEXICO: A REVIEW
}

\author{
Alberto González Gallina ${ }^{1, *} \&$ Griselda Benitez Badillo ${ }^{1}$ \\ ${ }^{1}$ Instituto de Ecología, AC, Carretera Antigua a Coatepec, №. 351, El Haya, Xalapa 91070, Veracruz, México. \\ E-mail: fodopo@hotmail.com, griselda.benitez@inecol.edu.mx
}

\begin{abstract}
The main goal of this study is to perform review of road ecology issue in Mexico. More specifically we addressed: 1) a general overview of road construction from pre-Colonial times to the present; 2) a description of the historical background context for understanding modern Mexico's highway system; 3) a review of the main results of the road ecology studies in Mexico and 4) the Mexican policy on mitigation actions. Finally, we discuss the key points of future research and road policies. There is already some research, mainly in road mortality, which gives us a glimpse of the impact of roads on Mexican wildlife. Mexico has wide diversity of habitats and ecosystems. So, to gain knowledge on the impact of roads on wildlife so that efficient corrective and preventive actions can be planned much more study is required. Unfortunately, most of the studies carried out in Latin America, and specifically in Mexico, were done only over Environmental Impact studies for large scale infrastructure projects. There is still a long way to go in Mexico for roadways to become environmentally friendly, but little by little the issue is gaining importance and hopefully more and more academics, policy makers and people in general will become interested and get involved, so that this goal can be achieved.
\end{abstract}

Keywords: Fauna; road-kill; public policy.

\section{RESUMO}

ESTUDOS DA ECOLOGIA DE ESTRADA DO MÉXICO: UMA REVISÃO. O principal objetivo deste estudo é revisar a questão da ecologia de estradas no México. Mais especificamente, abordados: 1) uma visão geral da construção de estradas desde a época pré-colonial até o presente, 2) uma descrição de sua origem para entender o sistema rodoviário do México moderno, 3) uma revisão dos principais resultados de estudos sobre ecologia de estrada no México e 4) a política mexicana de ações de mitigação. Por fim, discutimos os pontos chave para políticas e pesquisas futuras no assunto. Já existem resultados, principalmente sobre a mortalidade em estradas, que nos dão uma ideia de seu impacto sobre a fauna mexicana. O México tem grande diversidade de habitats e ecossistemas. Assim, para adquirir conhecimento sobre o impacto das estradas sobre a vida selvagem, de forma que eficientes ações corretivas e preventivas possam ser planejadas é necessário mais estudo. Infelizmente, a maioria dos estudos feitos na América Latina, e especificamente no México, têm sido realizados apenas durante Estudos de Impacto Ambiental de projetos de infraestrutura de grande porte. Há ainda um longo caminho a percorrer no México para que as estradas se tornem ambientalmente amigáveis, mas pouco a pouco a questão ganha importância e esperamos que mais e mais acadêmicos, tomadores de decisão, políticos, e o público em geral vão se interessar e se envolver, para que este objetivo pode ser alcançado.

Palavras-chave: Fauna; atropelamentos; políticas públicas.

\section{RESUMEN}

EN LA SENDA DE LA ECOLOGIA CARRETERA EN MEXICO. El objetivo principal de este estudio fue hacer una revisión del tema ecología de carreteras en México. Específicamente se enfocó a: 1) una 
revisión general de la construcción de caminos durante la época prehispánica; 2) una descripción desde sus antecedentes en el contexto histórico para entender el actual sistema carretero del país; 3) una revisión de los principales resultados de los estudios en ecología de carretera y 4) las políticas mexicanas sobre medidas de mitigación. Finalmente, se discuten algunos puntos clave sobre las políticas de investigación futuras. Aunque ya existen algunas investigaciones, principalmente sobre la mortalidad en carreteras, que dan una idea de su impacto sobre la fauna mexicana. Pero se requiere que además tomen en cuenta más la amplia diversidad de hábitats y ecosistemas para aumentar el conocimiento sobre el impacto de las carreteras en la fauna silvestre y sobre qué medidas correctivas pueden ser propuestas. Desafortunadamente, la mayoría de los estudios en América Latina, específicamente en México, han sido llevados a cabo bajo el cobijo de los Estudios de Impacto Ambiental y solamente para grandes obras de infraestructura. Hay aún un largo camino que recorrer para que las carreteras sean amigables con el ambiente, pero poco a poco el tema está ganando terreno y se espera, que más académicos, políticos, tomadores de decisiones y sociedad en general se interese e involucre, así el objetivo se pueda lograr.

Palabras clave: Fauna; atropellamientos; política pública.

\section{INTRODUCTION}

The term Road Ecology was introduced to the English in 1998 by the landscape ecologist Richard T.T. Forman (Forman 1998) who was studying the interactions between organisms and their environment in connection with roads and vehicles. Road ecology explores the relationship between the natural environment and the road system (Forman et al. 2003). Studies on the effects of roads have been carried out for decades in Europe, Australia and North America (Bashore et al. 1985, Reijnen \& Foppen 1994, Hourdequin 2000, Seiler 2001, Lagos et al. 2012). Although there is little information for the tropics, in Latin America, the research is generally pioneering. Fortunately, some research has been performed in Brazil (Pfeifer et al. 2008, Cáceres et al. 2010, Ferreira da Cunha 2010), Colombia (Arroyave et al. 2006, Delgado-V. 2007), Costa Rica (Monge-Nájera 1996, Gómez-Figueroa \& MongeNájera 2000, Lobo-González et al. 2010), Panama (Laurence et al. 2009), Argentina (Comita 1984, Barri 2010), and also in México since 1991 which has led to define recommendations and take action to mitigate the negative effects of roadways and create a more environmentally sustainable system of roadway development. In fact, several studies have been done in the context of Environmental Impact Assessment studies. In 2010, SELOME (FernándezBuces \& López-Noriega 2011) published a book of essays dealing with the main topics that make up the conceptual framework for understanding and applying environmental and legal-environmental aspects of road building.

Mexico is the fourth richest country in the world in terms of biological diversity (Mittermeier \& Mittermeier 1992) and the second most diverse country in terms of ecosystem diversity. Owing to its latitude, it is located at the convergence of the Nearctic and Neotropical biogeographic regions, resulting in the convergence of arid, humid, temperate and purely tropical regions. Mexico occupies second place in reptiles, fourth place in amphibians and, in general, a respectable place in the other orders, families and genera of flora and fauna. Mexico is considered a megadiverse country not only for its richness of plant and vertebrate species, but also in regards to its ecosystemic level. It is important to note that within the wide diversity of vegetation there is a variety of species composition and dominance. Rzedowski (1978) describes ten primary types of terrestrial vegetation, of which, only three vegetation types have been studied further tropical rainforest (3), tropical deciduous forest (1), semi-arid land and deserts (3) (See Figure 1). The Tropical rainforest and the deciduous comprise the greatest number of species. The site with the highest number of individuals was a semi-arid region in Perote, Veracruz (GonzálezGallina 2011, González-Gallina et al.2013) this could be attributed a one year of field work. 


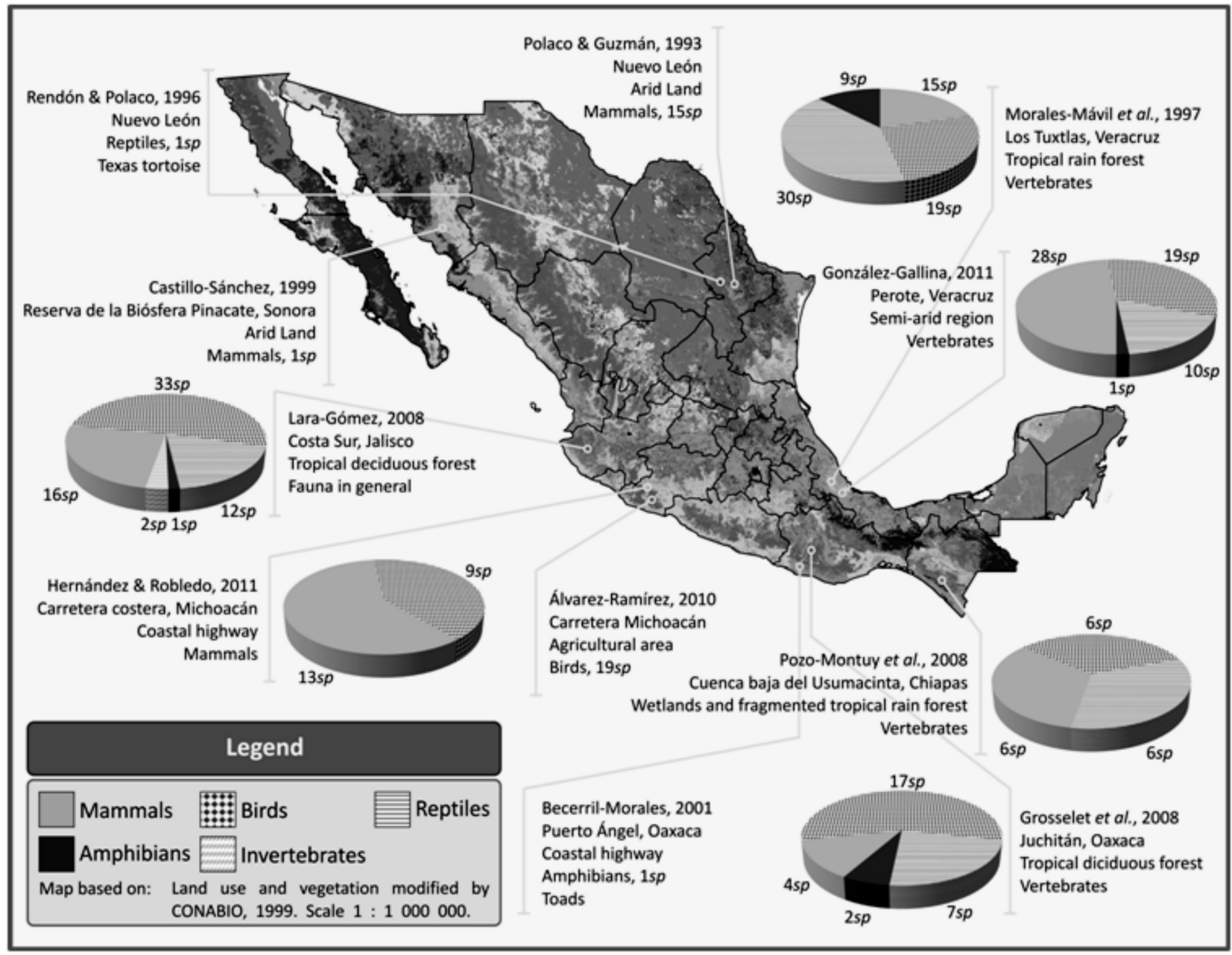

Figure 1. Summary of some road ecology studies carried out in Mexico.

The conservation of Mexico's extraordinary biodiversity is a huge challenge, especially considering the spatial patterns and current tendencies in land use, habitat degradation and the increase in the human population. In the last 50 years, Mexico has not escaped global tendencies and has suffered the drastic transformation of its natural environments by devastation or irreversible disturbance. Within its nearly two million square kilometers of land, there has been a huge number of changes that generally exceed the global mean; i.e. deforestation rates, increasing the area used for agricultural crops and pastures, urban expansion and many other changes that have been well documented (Mas et al. 2004, Sánchez-Colón et al. 2008) including roadways.

Due to the potential impact of roads on the high diversity and abundance of species, its emergent field has gained increased interest in Mexico. Our perception of the magnitude of the impact of roads on wildlife is changing to the degree so that researchers, environmentalist and engineers all recognize its importance. The initial damage from the construction of a road is deforestation. Particularly vulnerable are areas in southern Mexico, where it is covered by tropical rain forest and of concern due to the fact that the greatest biodiversity occurs here (González-Gallina 2011). Mexico suffers from an average deforestation rate between 492,100 (official sources) and 838,500 hectares per year (academic sources, Mas et al. 2009). In their final report, Jong et al. (2009) conclude that the occurrence of human settlements and roads are the factors that best explain the process of deforestation in Mexico's wet tropics.

The main goal of this study is to perform review of road ecology issue in Mexico. More specifically we addressed: 1) a general overview of road construction from pre-Colonial times to the present; 2) a description the historical background sets the context for understanding modern Mexico's highway system; 3) a review of the main results of the road 
ecology studies in Mexico and 4) the Mexican policy on mitigation measures. Finally, we discuss the key points of future research and road policies.

\section{A BRIEF HISTORY OF ROADS IN MEXICO}

The history of road building in Mexico may go back to prehispanic times. Some historic documents (i.e., Codex Sigüenza, Codex Laud, Codex Mendoza) say that in Mexico pre-conquest roads were simple openings in the forests and mountains (Fournier 2006, Sunyer-Martín 2011). Some of these roads were as wide as eight meters to facilitate the heavy traffic of travelers and numerous caravans of merchants, the pains (mail), tequipantitlatis (war messengers), the many topiles ortamemes (porters) of the pochtecas (traders), and military expeditions. The pre-Colonization network formed the nucleus from which the colonial system was established starting in 1521. To define the royal roadways (camino real) in the Americas, it is necessary to locate all the roads that during Spanish rule were named as such during the territorial integration of all Spanish America in accordance with the dictates of the Crown.

As a starting point, in 1573 there was a royal decree in The rules for discovery, new settlements and the pacification of the Indies (Ordenanzas de descubrimiento, nueva población y pacificación de las Indias given by Felipe II, 1573 that stated in Article 37 on "new settlements", that they "should have good sea ports and good routes by land and for navigation to facilitate commercial entry and export, governance, providing aid and for defense" (Pérez-González 2001). This ideal plan had the objective of linking new territories optimally and quickly, avoiding past errors. Maintenance of these key roads in the Americas began early and, in New Spain, started with the road from Veracruz to Mexico City for which traffic had increased notably since the founding of the Colony. The interest in this royal road, and later for the Mexico-Acapulco road, is obvious from economic and political points of view. Their importance is reflected in Humboldt's late $18^{\text {th }}$ century reference to these roads as "the road to Europe" and "the road to Asia", respectively. These roads guaranteed that the economic model imposed by the Crown would unfold smoothly. Both the mines and the roads that connected them were royal projects but for private use.

There appears to have been two types of royal roads in the Americas. Some are very long, such as the Camino Real de Tierra Adentro, from Mexico City to Santa Fe, New Mexico, the Camino Real de Chiapas from Mexico City to Guatemala, and the Camino Real de Lima from Peru to Venezuela. The strategic role of these long roads in consolidating the territory is obvious. There were other, shorter roads, that provided essential connections for everyday traffic (commerce, etc.), such as the Camino Real de Veracruz and the Camino Real de Acapulco. "The road built by the Crown, is wider than others, apt for carriages, and connects settlements of a certain importance" (Diccionario Enciclopédico Abreviado, 1957). This kind of definition reflects the process of organization that took place at the end of the $18^{\text {th }}$ and beginning of the $19^{\text {th }}$ centuries. At that time, the increasing strength of the Crown made it possible to create the institutions necessary to control the roads. With these institutions, as seen in the legislation of the time, it was finally possible to undertake improving road use and maintenance. The royal roads of the Americas perhaps made it possible - as no other institution could - to connect these new lands and their inhabitants to the rest of the Spanish Empire. Almost from the times the provinces they cross were named (Pérez-González 2001).

\section{MEXICAN ROADS TODAY}

The process of planning and designing roads in Mexico has evolved in the last 50 years. The changes in new urban developments and the modernization of the existing road network require an interdisciplinary approach to sustainability. This way the roads will meet the needs of all of those who use them, without sacrificing safety or efficiency, and will provide public spaces that improve the quality of life for everyone. A fundamental premise is to conserve the natural capital with the intention of keeping it available for future generations both directly and by avoiding its transformation or destruction.

In Mexico in 2007, public and private investment in the roadway, railway, airway and port-maritime subsectors was approximately 2345.4 million USA 
dollars (in 2007 Mexican pesos), which represents an increase of $7.3 \%$ over the previous year. Of this amount, 95.9\% was earmarked for roadway infrastructure, which essentially stayed at the same percentage of investment relative to the other types of transport. Investment in highways decreased in 1999, but has been increasing since 2003 .

Mexico's national highway system is the backbone of the transport system. It is by land, and particularly on the highways, that $53 \%$ of the national freight and $98 \%$ of travelling people move around the country. Around 479 million tons of goods and 3,170 million people are transported by vehicles each year. It is estimated that by 2007 the national roadway network was longer than $360,000 \mathrm{~km}$, and of this, $35 \%$ was paved roads and $64.7 \%$ unpaved. Paved roads accounted for more than $127,000 \mathrm{~km}$ of which 91\% were two-lane highways and the rest highways with four or more lanes. Unpaved roads accounted for $232,000 \mathrm{~km}$, with $67 \%$ graded roads, and $33 \%$ improved dirt roads and trails (SCT \& IMT 2010).

In 2008 road production was more than 49,750 million USA dollars (in 2003 Mexican pesos), and represented 7\% of the Gross National Added Value. As a goal for 2012, Mexico intends to build and upgrade $17,598 \mathrm{~km}$ of highways and rural roads, including $12,260 \mathrm{~km}$ as part of the completion of 100 highway projects, with an investment of 287000 million USA dollars (SCT 2007).

Mexico has opted for roadway transport instead of using other terrestrial routes such as the railways. This choice is most evident in the evolution of the gross added value for the transport sector and the subsector of warehouse services. From 2003 to 2008, the cargo transport sector increased 5.1\% (while railways increased $0.5 \%$ ) and brought in 21,411 million USA dollars (vs. 889 million USA dollars for railways). It was during the presidencies of Porfirio Díaz (1877-80, 1884-1911) that investment in the railway infrastructure was greatest, but growth in this sector began to stagnate thereafter and was null, at least from 1996 to 2004 (SCT \& IMT 2009).

\section{MEXICAN PUBLIC POLICY}

The environmental management of roads in Mexico began at the end of the 1980s with the passing of federal environmental laws, but the laws are not widely known, and road engineers are only vaguely familiar with them. This is mainly due to the poor integration of concepts within the legal framework and the technical reference framework; even though these should be simple and accessible to all of the professionals, technicians and others involved in building roads. Knowledge of the environmental management of road projects in Mexico is diffuse and has not been properly communicated to those involved in building roads and highways.

The main monitoring techniques and indicators of the impact of roads on the environment come from Europe. The Mexican Institute of Transport (el Instituto Mexicano del Transporte, IMT) has been implemented studies to monitor the environment along some national highways and to propose pertinent measures to create sustainable or green highways. In Mexico, environmental monitoring has been included in road-building projects in the form of mitigation measures implemented for the conservation or restoration of flora and fauna. In an early stage, such as when roads begin to operate, programs are set up to monitor reforestation areas, the functionality of rights-of-way for fauna, the efficiency of measures for the protection of wildlife species, and to evaluate the functioning of the mitigation measures implemented in the roadway project.

There also long term monitoring plans, three to five years after the roadway is opened for use, and during which fauna mortality and the progress of restored vegetation are surveyed, quantitative before-andafter comparisons are done of the different mitigation measures and the development of the habitats is evaluated. Monitoring has only been included in some roadway projects owing to economic constraints that limit the staff and resources necessary for monitoring the entire roadway network (Escalona 2012, Facultad de Ingeniería 2012). Currently, researchers are carrying out environmental monitoring programs for flagship species of fauna. For example: jaguar (Panthera onca) (Manterola et al. 2011), prairie dogs (Cynomys mexicanus), the volcano rabbit named "teporingo" (Romerolagus diazi) and mexican burrowing frog (Smilisca dentanta).

They are also working to establish suitable limits for the protection of human health and biodiversity, as well as to implement the necessary mitigation measures to control environmental impact (Mendoza- 
Sánchez et al. 2010). A highway built this way is known as a green or sustainable highway. So far, the Lerma-Tres Marías highway is being called the first green highway in the country due to all the environmental prone actions taken during the project, including trying to support conservation efforts for some endemic endangered species such as an axolotl (Ambystoma lermaense) and the volcano rabbit (Romerolagus diazi) (Mejía-Ramírez 2011).

\section{ROAD ECOLOGY STUDIES IN MEXICO}

Studies of the impact of roadways on Mexican wildlife have only been done since 1991, and have mainly focused on vertebrate road-kill on different stretches of road. Mexico has 32 states, of which, only $10(33 \%)$ have scientific papers related on road ecology. In Mexico there are three different sources of information together: peer-reviewed research articles, congress proceedings and Environment Impact Assessment studies. In the case of Mexico, most of references correspond to Environmental Impact Assessment (EIA) studies. We found few published scientific articles (16), only one of which is in a journal with high international circulation (Gutzwiller \& Barrow 2003). In the last special issue of Ecology and Society (Van der Ree 2011), 17 papers were from Australia, Canada, the Netherlands and USA and none from Mexico or from other Latin America country.

\section{SCIENTIFIC RESEARCH RESULTS}

Table 1 shows all the studies done for Mexico and Figure 1 shows only the studies with more species, starting with the work of Polaco \& Guzmán (1991, 1992 \& 1993) and Guzmán \& Polaco (1996). In their first study, they compared the number of specimens obtained for biological collections with wildlifevehicle collisions. They estimated from 290,175 to 2,031,225 mammals are hit by vehicles each year in the entire country. Their third study was done in an arid region of the state of Nuevo León in different types of vegetation and the last one in Sinaloa with barn owl (Tyto alba). Over the course of two days Rendon \& Polaco (1996) found seven land tortoises (Gopherus berlandieri) had been run over along $194 \mathrm{~km}$; four of them female. The region of Los Tuxtlas, Veracruz has one of the few conserved tropical rainforests in the country (Los Tuxtlas Biosphere Reserve), however the reserve is rather fragmented, and Morales-Mávil et al. (1997) found that during periods of increased activity such as spring and summer (the breeding period) there is an increase in the number of roadkills.

In Oaxaca, Becerril-Morales (2001) focused on a toad species (Bufo marinus) and estimated that along $1 \mathrm{~km}$ of highway, 2.3 to 6.4 toads are run over each day $(1,260$ per year). It was also found to be the species most road-killed in the Pantanos de Centla Biosphere Reserve, located in the northeastern corner of the Mexican state of Tabasco (CruzHernández, 2012). Gutzwiller \& Barrown (2003) studied bird communities in protected Chihuahuan Desert landscapes. Starting in 2008, the topic began to receive more attention with the publication of three additional studies. Also Grosselet et al. (2008) worked in a tropical deciduous forest in the state of Oaxaca, good region for wind farms, and reported an estimated 0.82 birds are killed each day, i.e., 1,642 per year, along a $1.2 \mathrm{~km}$ stretch road. Lara-Gómez (2008) also worked in a tropical deciduous forest on the coast of Jalisco, and Pozo-Montuy et al. (2008) did a study in the southern lower Usumacinta River Basin (at the junction of the states of Campeche, Tabasco and Chiapas) where there are wetlands and highly fragmented forests and recorded $0.6 \mathrm{ind} / \mathrm{km}$.

Interestingly, Álvarez-Ramírez (2010) evaluated the correlation between the number of birds killed by vehicles and the use of pesticides in an agriculture area in the vicinity of roads, which reduce their reflexes by inhibiting cholinesterase. During the rainy season when more pesticides are applied, the birds that survived did not responded to stimuli and cholinesterase activity was minimal. The study by Delgado-Trejo et al. (2011) in Michoacán, was done on the coastal highway and reports one dead animal every $11.6 \mathrm{~km}$. The most recent studies are by González-Gallina (2011 and 2013) in the semiarid region of Veracruz, with one study done in Veracruz in which they report that over $14 \mathrm{~km}$ there was an average of $33 \mathrm{ind} / \mathrm{km} /$ day. González-Gallina et al. (2013) looked at the richness and abundance of vertebrate roadkills and highlights the need for designing and applying policies and actions for road construction and maintenance. 


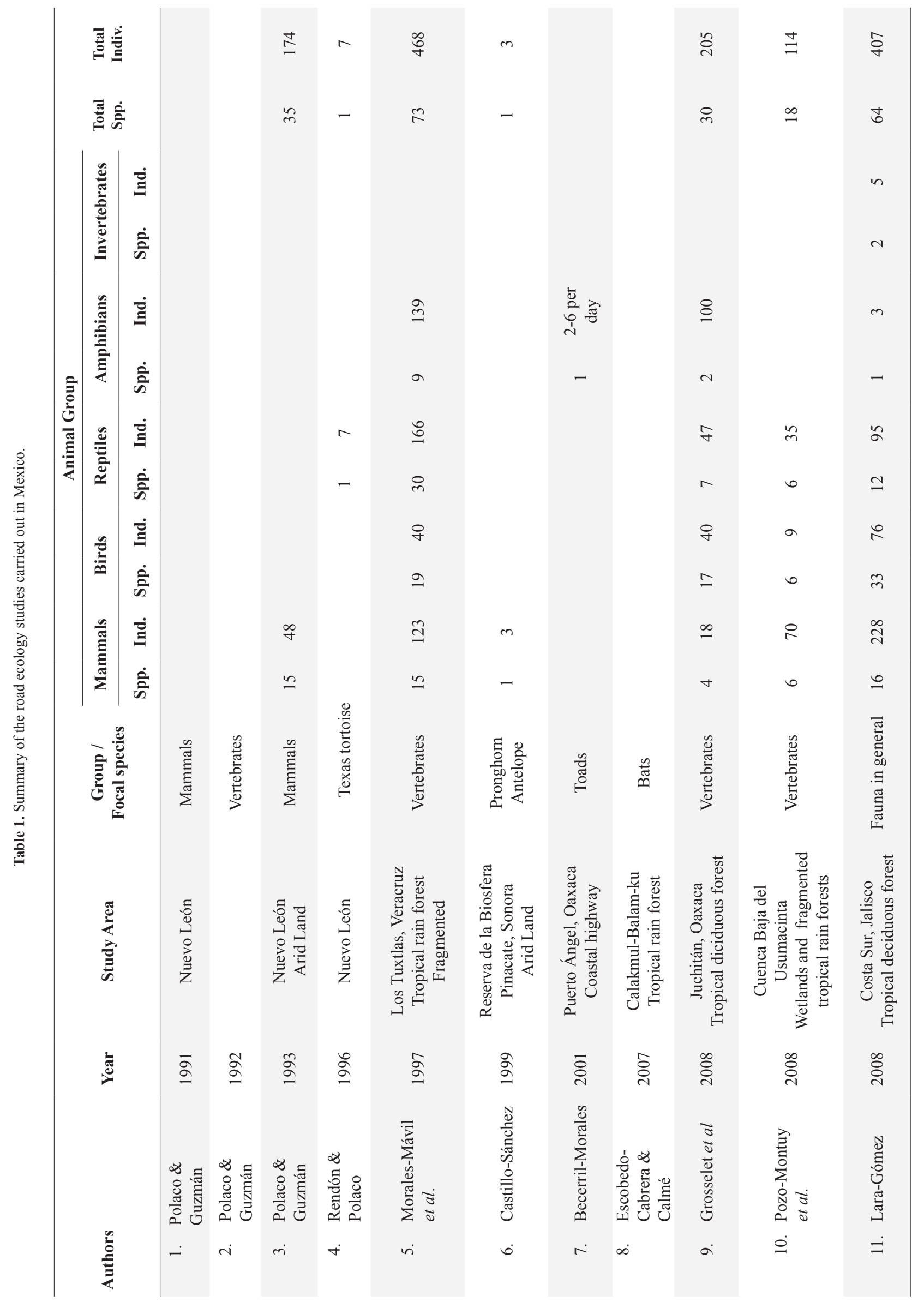




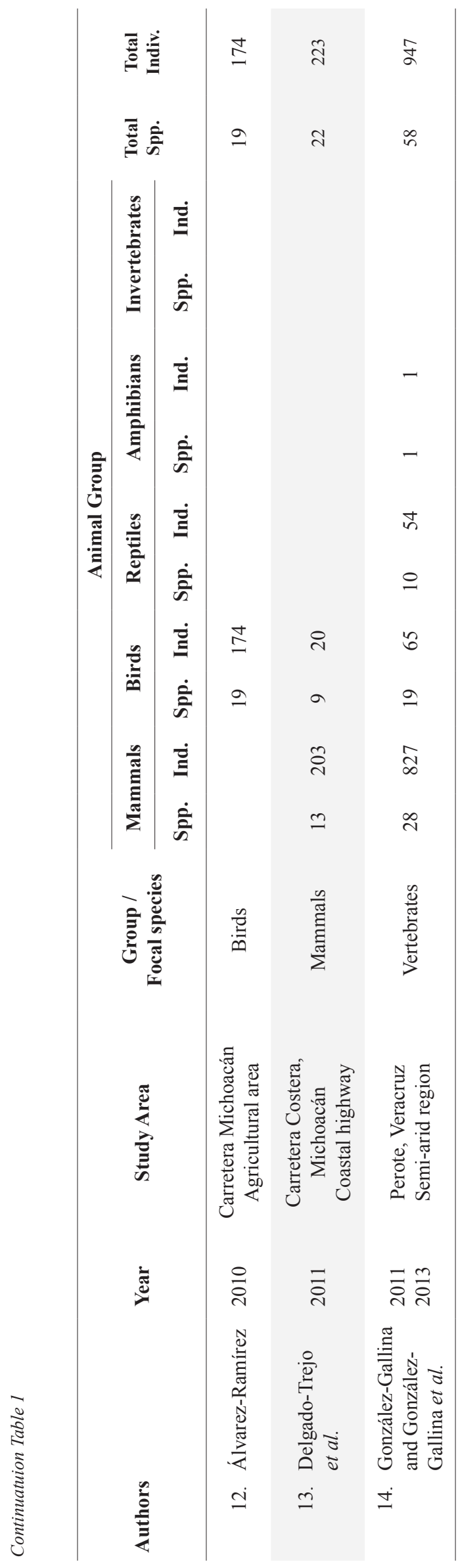

Escobedo-Cabrera \& Calmé (2005) studied a cave in Calakmul, Campeche called Bat Volcano (Volcán de los Murciélagos) with an estimated population of 2.5 million bats, located less than 400 meters from the highway. There are thirteen bats killed daily per $100 \mathrm{~m}$ of highway. From that project, two videos were produced about Highway 186 from Calakmulto Balam-Ku in Campeche that briefly explain the impact of roads on fauna, and the impact on the bat colony (EASAC \& EPOMEX 2010, SCT et al. 2011).

In addition to these studies on fauna that are run over, there are others that focus on priority species, such as the pronghorn Antilocapra americana. Castillo-Sánchez (1999) found evidence that this artiodactyl was crossing the interstate highways in the Pinacate Biosphere Reserve. Previously, it was thought that there was no communication between the Mexican and American populations in the Altar Desert. He also reported that some of the animals were run over when crossing the highway. This highlights the fact that widening highways (e.g. from 2 lanes to 4) increases the risk of mortality for other species, including the pronghorn, when they cross the roads. For the jaguar (Panthera onca), an emblematic species in Mexico, roads and highways are known to be one of the biggest national threats and as such, distance to roads is one of the most commonly used variables in studies that model the probable distribution of such animals (Ceballos et al. 2006). In Mexico, the study of roadkilled fauna has provided additional records and increased our knowledge of species distribution (Martínez-Ku et al. 2007, Martínez-Calderas 2009).

Ramírez-Ramírez et al. (2005) studied the network of roads that cross the Monarch Butterfly (Danaus plexippus) Biosphere Reserve, and concluded that road density within the reserve $\left(4.7 \mathrm{ind} / \mathrm{km}^{2}\right)$ is very high, even for a logging area. They mention the importance of working with the land owners to develop mechanisms for redesigning the roadway network and restoring the vegetation along some of the roads in order to reduce road density inside the forest, increase transportation efficiency and reduce damage to the forest. López-Cobos et al. (2011) states that in tropical sub-deciduous forest, in addition to facilitating the deforestation of native species, road building also results in the introduction of both native and exotic species of by providing them with suitable conditions The effect of roads on species distribution 
and dispersal is an important conservation and management issue (Watkins et al. 2003).

\section{CONGRESS PROCEEDINGS}

In Mexico, during 2011 the impact of roadways on different levels was a key theme at three large events. Among the objectives of the first were to promote and stimulate the development of new workshops in other parts of the country and in Latin America. In the second, the objective was to compare techniques and experiences with experts from all over the world in the area of highway infrastructure. The third conference discussed topics related to biodiversity, among others. There was a presentation entitled The Ecological Impacts of Transportation Infrastructure, based on interviews with relevant professionals and reviewing their experiences of implementing measures for mitigating ecological impact in EIA studies on regional scale infrastructure planning procedures (Karlson et al. 2011), and another, entitled Landscape Level Ecological Impact Assessment, dealing with GIS-based habitat models and tools developed for this scale of assessment of the impact of transportation infrastructure on biodiversity (Mortberg et al. 2011). Finally there was a workshop on the prospects for sustainable infrastructure in Mexico (Fernández del Castillo 2011), which addressed how the private sector contributes to sustainable infrastructure, and how it maximizes shared value for different stakeholders. In 2013 a Symposium on Environmental impact of roads were held in the IV Mexican Congress of Ecology in Villahermosa Tabasco (SCME 2013). The discussion tied in with both environmental impacts and mitigation measures of roads on fauna mainly. Seven lectures contributing to the analysis the threat for the conservation of biodiversity.

Table 2. Congress proceedings in Mexico.

\begin{tabular}{|c|c|c|}
\hline Congress & Place & Objective \\
\hline $\begin{array}{l}\text { IV International Workshop on the Impact } \\
\text { of Human Infrastructure on Wildlife in } \\
\text { Latin America } 2011 .\end{array}$ & $\begin{array}{l}\text { Universidad Juárez } \\
\text { Autónoma de Tabasco } \\
\text { (UJAT). Villahermosa } \\
\text { Tabasco }\end{array}$ & $\begin{array}{l}\text { To increase national awareness of the impact of } \\
\text { human infrastructure on our flora and fauna. }\end{array}$ \\
\hline
\end{tabular}

XXIV World Highway Congress 2011.

Mexico City

Impact Assessment and Responsible Development for Infrastructure, Business Puebla, Puebla and Industry (IAIA11) 2011.

IV Mexican Congress of Ecology: Ecological knowledge for the decision making 2013.
Universidad Juárez Autónoma de Tabasco (UJAT).Villahermosa Tabasco
More than 4,000 specialists from 100 countries participated, though little was said about the impact of roadways on fauna.

During a facilitated discussion, each of the speakers highlighted key underpinnings of the business case for sustainability and its strategic value. Perspectives were shared from the construction, and urban planning sectors.

Academic Congress, an ecological approach was assumed of the impacts and mitigation measures of roads on fauna.

\section{ENVIRONMENTAL IMPACT STUDIES}

Environmental impact assessment (EIA) studies are an important source of information about the effect of roads on fauna. Bojórquez \& García (1998) analyzed 33 EIAs done for roads (as a unifying criterion), and found that in general these studies provide inadequate descriptions and subjective evaluations of the different types of impact, and therefore fail to achieve their objective because they focus on the environmental conflicts caused by the EIA projects. Additionally, there is a series 
of technical documents produced by the Ministry of Communication and Transportation (la Secretaría de Comunicaciones y Transporte, Damián-Hernández \& Téllez-Gutiérrez 1998, Martínez-Soto \& DamiánHernández 1999, Damián-Hernández et al. 2000, Hernández-Michaca et al. 2000a, 2000b, HernándezMichaca et. al. 2001, SEMARNAT 2012), which have the objective of identifying the environmental impact generated by roadways and the required measures of mitigation, including how to make use of the right-ofway (SCT 1997). In spite of all the instruments that have been created for highway development, their application has been limited (Ezcurra 1995).

\section{MITIGATION MEASURES}

It is a big challenge to reduce highway mortality through mitigation measures. The simple and relatively inexpensive measures reviewed herein can almost certainly reduce the number of collisions between wildlife and vehicles. Martínez-Soto \& Damián-Hernández (1999) present a publication with some of the most important environmental impacts produced by road construction, and provide corresponding mitigation measures for those impacts. The mitigation measures are simple and intended for the highway engineers and managers in the transportation sector. They are proposed for the phases PreConstruction, Site Preparation, Construction, Operation and Maintenance. They analyzed 20 activities, detected 107 impacts and proposed 151 mitigation measures. The National Infrastructure Plan of Mexico (el Plan Nacional de Infraestructura, PNI) 2007-2012 defines a series of environmental criteria and guidelines for infrastructure development. They can be seen as preconstruction preventive mitigation measures: 1) apply formal methodologies and those with a specific aim of linear projects, for the selection of the route of the road building projects; 2) incorporate into the design guidelines to reduce as much as possible the effects on natural protected areas and on other conservation areas with high ecological and landscape value; and 3) incorporate into the design guidelines additional structures to prevent mortality: rights-of-way for animals, fencing systems, warning signs and barriers to prevent noise.

Some general recommendations considered in Mexican EIA regarding wildlife collision mitigation follow Glista et al. (2009) suggestions: 1) preconstruction planning is generally more economical than retrofitting existing roads and in the case of Mexico, it is considered during environmental impact assessment; 2) connectivity of habitat and permeability of road systems are important factors; 3) financial considerations may dictate nonstructural approaches to collision reduction, but structural methods are probably more effective (and more expensive) and 4) efficiency of road mortality mitigation approaches should be determined via a post-implementation monitoring program.

\section{DISCUSSION}

Considering the increase in roadway infrastructure, and the local nature of the studies that have been carried out in the country, we begin to get an idea of the impact of roadways on fauna. Much more study is required, especially to learn about Mexico's wide variety of habitats and landscapes and at least have a general idea of the impact of roadways on wildlife so that efficient corrective and preventive measures can be proposed. It is necessary to have the basic information that roadway ecology studies can provide, not only about road-kill, but also the impact of the barrier effect on some threatened populations. Unfortunately, most of the studies done in Latin America and specifically in Mexico have been carried out under the umbrella of environmental impact studies only for large scale infrastructure projects.

This information should be systematically collected and made available to the public in to order to provide a more complete view of the relationship between fauna and road building. Ideally, these studies would include information from before and after road construction in order to have a clearer understanding of the positive and negative road impacts. For highways, the most frequent corrective measures taken are replanting rights-of-way and. Although there are fauna rescue programs while the roads are being built they are not very effective.

In Mexico the use of Environmental Impact Assessment studies, applied as a purely preventative instrument, has - after nearly 30 years - failed to curb the trend of environmental degradation. This failure may be attributed to the limited application of the knowledge gained for a region, and the negatively 
synergistic effect that the impact of several projects may have. Further, there is an apparent lack of will to disseminate the information of such studies and many of them remain hidden in desks and drawers where no further use can be made out of them. Another reason is the fact that the last stage in the decision making process is rigid and leaves no room for alternatives. Strategic Environmental Evaluation should be incorporated as an environmental policy instrument that is preventative in nature and strengthens the current use of environmental impact studies. This requires the reformulation of Mexico's General Law for Ecological Equilibrium and Environmental Protection (Ley General del Equilibrio Ecológico y Protección al Ambiente, LEGEEPA, SEMARNAT 2011), because it is important that the authorities responsible determine which programs should be focused upon, establish a reference procedure and develop methodological frameworks and guidelines for its implementation. In the future, development policies that continue to give low priority to the conservation and management of biodiversity will be ignoring basic aspects of national security and the country's prospects, such as that of creating a viable, competitive society that has a sustainable material base.

As in many parts of the world, natural protected areas have been a focus of attention and have aided in the synergy of environmental concern movement (Garriga et al. 2012). Mexico is not an exception, several biosphere reserves, and national parksare crossed by or near a highway system. Despite this fact, out of all the scientific studies related to road ecology, we found only two related to actual protected areas such as Los Tuxtlas in Veracruz (MoralesMávil et al. 1997) and Pinacate in Sonora (CastilloSánchez 1999). Gutzwiller \& Barrow (2003) point out that the protected areas should receive special attention because they are important sources for indigenous species. The challenge for Mexico is to include, in different phases, the existing monitoring and environmental control programs, starting with the network of toll highways and continuing with toll-free roads, those that cross or pass by natural protected areas, those of high environmental value, and finally the remaining highway infrastructure.

There are probably more studies in the shape of gray literature that relate to this phenomenon and protected areas. Environmental agencies take interest and try to become more strict when a protected area is involved in a development project, nevertheless, it seems as is the trend in Mexican road-ecology studies, all research is forgotten within the EIA studies without any further scientific approach.

\section{CONCLUSIONS}

The future of road ecology research will be best enhanced when multiple road projects in different states or countries are combined and studied as part of integrated, well-replicated research projects. As can be seen in Mexico, there are ongoing projects approaching the idea of environmental responsibility for road planners and decision makers. However more research is needed concerning the efficacy of various road mortality mitigation programs. Road ecology is a fertile ground for research in places such as Mexico and we are positive there will be an increase in highway impact related studies in the years to come. It is necessary to consider study topics like the effect on population density, unequal effect of road-kill on sexes and their effect on reproductive success, dispersal of invasive species via roads, topics that have not yet been examined in Mexico. In the end, more experimental research is necessary to complement post hoc correlation studies in Mexico.

Finally, we must begin to visualize roads that are more in harmony with the environment, that facilitate new connectivity between separated populations in order to ensure species viability over the long term. That is why there are laws and mandates that prohibit, regulate and control the activities that could have a negative impact on the environment. In spite of the pressures imposed by development, these measures have made it possible to move toward the conservation of natural resources by reducing environmental degradation. There is still a long way to go in Mexico for roadways to become environmentally friendly, but little by little the issue is gaining importance and hopefully more and more academics, policy makers and people in general will become interested and get involved, so that this goal can be achieved.

ACKNOWLEDGMENTS: We thank Tom Langen for inviting us to participate in this special issue of Oecologia Australis. Bianca Delfosse translated the text from the original in Spanish. We want to express very special recognition and gratitude to anonymous referees for their valuable suggestions and constructive criticism of the manuscripts. 


\section{REFERENCES}

ÁlVAREZ-RAMÍREZ, M.T.; SALGADO-ORTIZ, H.J. \& VÁZQUEZ-MUÑOZ, M. 2010. Efecto de la aplicación de herbicidas en campos de cultivos en el número de aves atropelladas en las carreteras del occidente michoacano. In: Memorias del X Congreso para el estudio y conservación de aves en México (CECAM), Xalapa, Veracruz, México.

ARRIAGA-WEISS \& W.M. CONTRERAS-SÁNCHEZ (orgs.) Perspectivas en Zoología Mexicana, Universidad Juárez Autónoma de Tabasco, Tabasco, México. 265p.

ARROYAVE, M.P.; GÓMEZ, C.; GUTIÉRREZ, M.E.; MÚNERA, D.P.; ZAPATA, P.A.; VERGARA, I.C.; ANDRADE, L.M. \& RAMOS, K.C. 2006. Impactos de las carreteras sobre la fauna silvestre y sus principales medidas de manejo. Revista EIA, 5: 45-57.

BARRI, F.R. 2010. Evaluación preliminar de la mortandad de mastofauna nativa por colisión con vehículos en tres rutas argentinas. Ecología Aplicada, 9: 161-165.

BASHORE, T.L.; TZILKOWSKI, W.M. \& BELLIS, E.D. 1985. Analysis of deer-vehicle collision sites in Pennsylvania. Journal of Wildlife Management, 49: 769-74.

BECERRIL-MORALES, F. 2001. Sapos atropellados: mortalidad no natural del sapo marino (Bufo marinus; Bufonidae), en Puerto Ángel, Oaxaca. Ciencias y Mar, 5(13): 47-52.

BOJÓRQUEZ-TAPIA, L.A. \& GARCÍA, O. 1998. An approach for evaluating EIAs -Deficiencies of EIA in Mexico. Environmental Impact Assessment Review, 8: 217-240, http://dx.doi.org/10.1016/ SD195-9255(98)00008-0

CÁCERES, N.C.; WELLINGTON, H.; FREITAS, D.R.; SILVA, E.L.; CASSIANO, R. \& CASELLA, J. 2010. Mammal occurrence and roadkill in two adjacent ecoregions (Atlantic Forest and Cerrado) in south-western Brazil. Zoologia, 27: 709-717, http:// dx.doi.org/10.1590/S1984-46702010000500007

CASTILLO-SÁNCHEZ， C. 1999. Highways and wildlife conservation in Mexico. The Sonora pronghorn antelope at the El Pinacate y Gran Desierto de Altar Biosphere Reserve along the Mexico-USA border. In: Proceedings International Conference on Wildlife Ecology and Transportation, Minnesota, Montana, U.S.A.

CEBAllos, G.; CHÁVEZ, C.; BLANCO, S.; JIMÉNEZ, R.; LÓPEZ, M.; MOCTEZUMA, O.; TAMEZ, V. \& VALDEZ. M. 2006. Áreas prioritarias para la conservación. Pp. 13-19. In: C. Chávez \& G. Ceballos (eds.). Memorias del Primer simposio El jaguar mexicano en el siglo XXI: situación actual y manejo. Cuernavaca, Morelos, México.
COMITA, J.L. 1984. Impacto de los caminos sobre la fauna en el Parque Nacional El Palmar. Revista del Museo Argentino de Ciencias Naturales "Bernardino Rivadavia" e Instituto Nacional de la Investigación de las Ciencias Naturales. Zoología, 13: 513-521.

CRUZ-HERNÁNDEZ， Y.S.; PACHECO-FIGUERO， C.J.; GORDILLO-CHÁVEZ, E.J.; VALDEZ-LEAL， J. de D.; MOGUEL-ORDOÑEZ, E.; SAENZ, J. \& GAMA-CAMPILLO. W. 2012. Caracterización de la fauna silvestre atropellada en un tramo carretero de la reserva de la biosfera Pantanos de Centla. Pp. 115-119. In Chablé-Falcón F. Angulo-Pineda R.; PavónJiménez M.E. Gregorio Cano-Molina, G. Méndez-Hernández, W. (Compiladores) Perspectiva científica desde la UJAT. Tomo 1. Universidad Autónoma de Tabasco, Tabasco México. 1115 pp. ISBN: 978-607-606-092-6 http://www.archivos.ujat. $\mathrm{mx} / 2013$ /investigacion_posgrado /investigacion/Perspectiva $\% 20$ Cient\%C3\%ADfica\%20desde\%201a\%20UJAT_SDD12.pdf

DAMIÁN-HERNÁNDEZ, S.A. \& TÉLLEZ-GUTIÉRREZ, R. 1998. Consideraciones sobre el medio ambiente en la planeación de carreteras. Publicación Técnica ${ }^{\circ}$ 102. Instituto Mexicano del Transporte. Sanfalia, Qro, Distrito Federal, México. 85p.

DAMIÁN-HERNÁNDEZ， S.A.; MARTÍNEZ-SOTO, A. \& AGUIRRE-PÉREZ, J.M. 2000. Impacto ambiental de proyectos carreteros. Efectos por la explotación de bancos de materiales y construcción. Publicación Técnica $n^{\circ}$ 145. Instituto Mexicano del Transporte. Sanfandila, Qro, Distrito Federal, México. 87p.

DELGADO-TREJO, C.; HERNÁNDEZ, N. \& ROBLEDOHERRERA, R. 2011. Mortalidad de vertebrados silvestres en la carretera costera de Michoacán. INIRENA. http://www.inirena. umich.mx/\&carretera.html.

DELGADO-V., C.A. 2007. Muerte de mamíferos por vehículos en la vía del Escobero, Envigado (Antioquia), Colombia. Actual Biol., 29: 235-239. http://www.scielo.org.co/pdf/acbi/v29n87/ v29n87a7.pdf

Diccionario Enciclopédico Abreviado. 1957. 7 Volumes + One Appendix. Espasa-Calpe, Madrid.

EASAC (Ecología Aplicada del Sureste A.C.) \& EPOMEX (Centro de Ecología Pesquerías y Oceanografía del Golfo de México). 2010. Efectos de las carreteras sobre la distribución de fauna en Calakmul y Balam-ku. <http://www.youtube.com/ watch?v=NvLFsPwZdjQ>. (Accessed 17/02/2012).

ESCALONA, G. 2012. Programa de manejo de la cueva "el volcán de los murciélagos" Calakmul, Campeche. Publicación Técnica. Investigaciones Jurídicas de la Universidad Autónoma de Campeche (UAC), Instituto de Ecología, Pesquerias y 
Oceanografias del Golfo de Mexico (EPOMEX-UAC), Universidad Autónoma de Tamaulipas (UAT).

ESCOBEDO-CABRERA, E. \& CALMÉ, Y.S. 2005. Subproyecto Murciélagos. Pp. 1-39. In: Uso y Monitoreo de los Recursos Naturales en el Corredor Biológico Mesoamericano (Áreas Focales Xpujil-Zoh Laguna y Carrillo Puerto, Pozo, C. y S. Calmé, Responsables). Clave BJ002. Reporte Técnico. El Colegio de la Frontera Sur - Comisión Nacional para el Conocimiento y Uso de la Biodiversidad (ECOSUR-CONABIO).

EZCURRA, E. 1995. Las manifestaciones de impacto ambiental. Un análisis crítico. Gaceta Ecológica, 36: 8-14.

FACULTAD DE INGENIERÍA, 2012. Diseño de carreteras para proteger flora y fauna de las principales cruces carreteros en Chihuahua, Chihuahua. Universidad Autónoma de Chihuahua. http://www.elobservador.mx/index.php/chihuahua/principalgrande/9096-realizaran-diseno-de-carreteras-para-proteger-floray-fauna

FERNÁNDEZ-BUCES，N. \& LÓPEZ-NORIEGA，S.A. eds. 2011. Un camino sustentable. La gestión ambiental de carreteras en México. Compilación de ensayos. Grupo SELOME. 306p. http://selome.com.mx/SelomeLibro.pdf

FERNÁNDEZ DELCASTILLO,A.P. 2011. Mexican perspectives on sustainable infraestructure. Workshop in Conference on IAIA 2011, Puebla, México.

FERREIRA DA CUNHA, H.; ALVES MOREIRA, F.G. \& SOUSA SILVA, S. 2010. Roadkill of wild vertebrates along the GO-060 road between Goiania and Iporá, Goiás State, Brazil. Acta Scientiarum. Biological Sciences, 32: 257-263, http://dx.doi. org/10.4025/actascibiolsci.v32i3.4752

FORMAN, R.T.T. \& ALEXANDER, L.E. 1998. Roads y their major ecological effects. Annual Review of Ecology and Systematics, 29: 207-231.

FORMAN， R.T.T.; SPERLING， D.; BISSONETTE， J.A.; CLEVENGER, A.P.; CUTSHALL, C.D.; DALE, V.H.; FAHRIG,

L.; FRANCE, R.; GOLDMAN, C.R.; HEANUE, K.; JONES, J.A.; SWANSON, F.J.; TURRENTINE, T. \& WINTER, T.C. 2003. Road Ecology: Science and Solutions. Island Press, Washington DC USA. 441p.

FOURNIER, P. 2006. Arqueología de los caminos prehispánicos y coloniales. 2006. Revista Arqueología Mexicana, XIV(81): 2631. http://www.arqueomex.com/S2N3nCAMINOS81.html

GARRIGA, N.; SANTOS, X.; MONTORI, A.; RICHTER-BOIX, A.; FRANCH M. \& LLORENTE, G.A. 2012. Are protected areas truly protected? The impact of road traffic on vertebrate fauna.
Biodiversity and Conservation, 21: 2761-2774, http://dx.doi. org/10.1007/s10531-012-0332-0

GLISTA, D.J.; DEVAULT, T.L. \& DE WOODY, J.A. 2009. A review of mitigation measures for reducing wildlife mortality on roadways. Landscape and Urban Planning, 91: 1-7, http://dx.doi. org/10.1016/j.landurbplan.2008.11.001

GÓMEZ-FIGUEROA， P. \& MONGE-NÁJERA， J. 2000. Fauna silvestre víctima de las carreteras: El caso de Costa Rica. Repertorio Cientifico, 6:47-50.

GONZÁLEZ-GALLINA, A. 2011. Atropellamiento de fauna en el libramiento carretero de Amozoc-Cantona- Perote (20102011). Tesis de Maestría, INECOL. 82p.

GONZÁLEZ-GALLINA， A.; BENÍTEZ-BADILLO， G.; ROJAS-SOTO, O.R. \& HIDALGO-MIHAR, M.G. 2013. The small, the forgotten and the dead: highway impact on vertebrates and its implications for mitigation strategies. Biodiversity and Conservation, 22(2): 325-342

GROSSELET, M.; VILLA-BONILLA, B. \& RUIZ-MICHAEL, G. 2008. Afectaciones a vertebrados por vehículos automotores en $1.2 \mathrm{~km}$ de carretera en el Istmo de Tehuantepec. Pp. 227-231. In: T.D. Rich, C. Arizmendi, D.W. Demarest \& C. Thompson (eds.). Tundra to Tropics: connecting birds, habitats and people. Proceedings of the Fourth International Partners in Flight Conference, McAllen, Texas, U.S.A.

GUTZWILLER, K.J. \& BARROW, W.C. JR. 2003. Influences of roads and development on bird communities in protected Chihuahuan Desert landscapes. Biological Conservation, 113: 225-237, http://dx.doi.org/10.1016/S0006-3207(02)00361-0

GUZMÁN, A.F. \& POLACO, O.J. 1996. Mortalidad en carretera de la lechuza común Tyto alba (Scopoly, 1769) (AVES:STRYGIDAE) en Sinaloa, México. Vertebrata Mexicana, 1: $1-5$.

HERNÁNDEZ-MICHACA， J.L.; PISANTY-LEVY， J.; SÁNCHEZ-GRANADOS, V.M.; CARREÓN-MÉNDEZ, M.A. \& ROLDÁN-ORTÍZ, M. 2000a. Impacto ambiental de proyectos carreteros por la construcción y operación de túneles. Publicación Técnica $n^{\circ}$. 146. Instituto Mexicano del Transporte, Sanfandila, Qro, Distrito Federal, México. 96p.

HERNÁNDEZ-MICHACA， J.L.; SÁNCHEZ-GRANADOS, V.M.; CASTILLO-CHAIRES， I.; DEMIÁN-HERNÁNDEZ, S.A. \& TÉLLEZ-GUTIÉRREZ, R. 2000b. Impacto ambiental de proyectos carreteros. Efectos por la construcción y conservación de superficies de rodamiento I: pavimentos flexibles. Publicación Técnica $n^{\circ}$ 163. Instituto Mexicano del Transporte, Sanfandila, Qro, Distrito Federal, México. 167p. 
HERNÁNDEZ-MICHACA， J.L.; SÁNCHEZ-GRANADOS, V.M.; CASTILLO-CHAIRES, I.; DEMIÁN-HERNÁNDEZ, S.A. \& TÉLLEZ-GUTIÉRREZ, R. 2001. Impacto ambiental de proyectos carreteros. Efectos por la construcción y conservación de superficies de rodamiento II: pavimentos rígidos. Publicación Técnica $n^{\circ}$ 173. Instituto Mexicano del Transporte, Sanfandila, Qro, Distrito Federal, México. 120p.

HOURDEQUIN, M. (ed). 2000. The ecological effects of roads. Special issue of Conservation Biology 14(1): 16-94.

KARLSON, M.; BALFORS, B.; ERLANDSSON, A.; HEDLUND, A.; LINDBOLM, U.; LUNDBERG, K. \& MÖRTBERG, U. 2011. Ecological impacts of transport infrastructure. Conference on IAIA 2011, Puebla, México.

LAGOS, L.: PICOS, J. \& VALERO, E. 2012. Temporal pattern of wild ungulate-related traffic accidents in northwest Spain. European Journal of Wildlife Research, 58(4): 661-668, http:// dx.doi.org/10.1007/s10344-012-0614-6

LARA-GÓMEZ, G. 2008. Mortalidad de fauna Silvestre por Infraestructura Carretera en la Región 08 Costa Sur del Estado de Jalisco, México. Pp. 235-250. In: A.J. Sánchez, M.G. Hidalgo-Mihart, S.L. Arriaga-Weiss \& W.M. Contreras-Sánchez (orgs.) Perspectivas en Zoología Mexicana, Universidad Juárez Autónoma de Tabasco, Tabasco, México. 265p.

LAURENCE, W.F.; GOOSEM, M. \& LAURENCE, S.G.W. 2009. Impacts of roads and linear clearings on tropical forests. Trends in Ecology \& Evolution, 24(12): 659-669, http://dx.doi. org/10.1016/j.tree.2009.06.009

LOBO-GONZÁLEZ, H.; LANGEN, T.; SÁENZ, J. \& SPINOLA, M. 2010. Mortalidad de herpetofauna por atropello en la Carretera Interamericana Norte, Área de conservación Guanacaste, Costa Rica. Mesoamericana, 14(2): 36.

LÓPEZ-COBOS,E.; MEDINAVAN-BERKUM,P.; RODIRGUEZLARA, P.E. \& ZAPATA-LUNA, R.L. 2011. Carreteras: ¿Vías de comunicación para la gente o vías de comunicación de las especies invasoras? Mesoamericana 15(2): 260.

MANTEROLA, C.; CONDE-AMOR, D.; COLCHERO, F.; RIVERA, A.; HUERTA, E.: SOLER, A. \& PALLARES, E. 2011. El jaguar como elemento estratégico para la conservación. Corredor Biológico Mesoamericano México Serie Acciones / Número 8. Comisión Nacional para el Conocimiento y Uso de la Biodiversidad, Distrito Federal, México. 126p.

MARTÍNEZ-CALDERAS, J.M. 2009. Nuevos registros y distribución del ocelote (Leopardus pardalis) en el noroeste de México. M.Sc. Thesis. Colegio de Postgraduados Campus Montecillo. 96p.
MARTÍNEZ-KÚ, D.H.; ESCALONA-SEGURA, G. \& VARGASCONTRERAS, J.A. 2007. Primer registro del zorrillo manchado del sur Spilogale angustifrons Howell 1902 para el estado de Campeche, México. Acta Zoológica Mexicana (nueva serie), 23:175-177.

MARTÍNEZ-SOTO, A. \& DAMIÁN-HERNÁNDEZ, S.A. 1999. Catálogo de impactos ambientales generados por las carreteras y sus medidas de mitigación. Publicación Técnica $n^{\circ}$ 133. Instituto Mexicano del Transporte, Sanfalia, Qro, Distrito Federal, México. 85p.

MAS, J.F.; VELÁZQUEZ, A. \& COUTURIER, S. 2009. La evaluación de los cambios de cobertura/uso del suelo en la República Mexicana. Investigación Ambiental. 1(1): 23-39.

MEJÍA-RAMÍREZ, B.J. 2011. Autopista Lerma-Tres Marías Un Proyecto Carretero en Armonía Ambiental. Tesis para obtener el título de Licenciado en Comunicación y Periodismo. Facultad de Estudios Superiores Aragón, Universidad Nacional Autónoma de México (UNAM), Estado de México, México.

MENDOZA-SÁNCHEZ, J.F.; LÓPEZ-DOMÍNGUEZ, M.G. \& TÉLlEZ-GUTIÉRREZ, R. 2010. Monitoreo ambiental en carreteras. Vias Terrestres, 6: 20-23.

MITTERMEIER, R. \& MITTERMEIER. C.G. 1992. La importancia de la diversidad biológica de México. Pp. 6373. In: J. Sarukhán \& R. Dirzo (orgs.). México ante los retos de la biodiversidad. Comisión Nacional para el Conocimiento y Uso de la Biodiversidad, México. 343p.

MONGE-NÁJERA, J. 1996. Vertebrate mortality on tropical highways: the Costa Rican case. Vida Silvestre. Neotropical, 5(2): 47-50.

MORALES-MÁVIL, J.E.; VILLA-CAÑEDO, J.T., AGUILARRODRÍGUEZ, S. \& BARRAGÁN-MORALES, L.1997. Mortalidad de vertebrados silvestres en una carretera asfaltada de la región de Los Tuxtlas, Veracruz, México. Ciencia y el Hombre-UV, 27: 7-23.

MÖRTBERG, U.; KARLSON, M. \& BALFORS B. 2011. Landscape level ecological impact assessment. Conference on IAIA 2011, Puebla, México.

PÉREZ-GONZÁLEZ, M.L. 2001. Los caminos reales de América en la legislación y en la historia. Anuario de Estudios Americanos, 58: 33-60, http://dx.doi.org/10.3989/aeamer.2001. v58.i1.227

PFEIFER, I.; KINDEL, A. \& PFEIFER, C.A.V. 2008. Roadkills of vertebrate species on two highways through the Atlantic Forest Biosphere Reserve, southern Brazil. European Journal of Wildlife Restoration 54: 689-99, http://dx.doi.org/10.1007/s10344-008$0197-4$ 
POLACO, O.J. \& GUZMÁN, A.F. 1991. Mortalidad animal en carretera y colectas biológicas. Zoología Informa. 23: 1-7.

POLACO, O.J. \& GUZMÁN, A.F. 1992. Mortalidad animal de vertebrados silvestres en las carreteras de México. Pp. 48-53. In: X Simposio sobre fauna silvestre "Gral. MV Manuel Cabrera Valtierra": Universidad Nacional Autónoma de México (UNAM), México.

POLACO, O.J. \& GUZMÁN, A.F.1993. Mortalidad anual de mamíferos en una carretera al sur de Nuevo León. Pp: 395-408. In: R. Medellin \& G. Ceballos (eds). Avances en el Estudio de Mamíferos de México. Asociación Mexicana de Mastozoología, Distrito Federal, México. 463p.

POZO-MONTUY, G.; BONILLA-SÁNCHEZ, M. \& POZOJUAREZ, F. 2008. Las carreteras y su impacto sobre la fauna silvestre en una región de la Cuenca Baja del Usumacinta. In: A.J. Sánchez, M.G. Hidalgo-Mihart, S.L Perspectivas en Zoología Mexicana. Universidad Autónoma de Tabasco, Tabasco. México. Pp. 251-265.

RAMÍREZ-RAMÍREZ, M.I.; JIMÉNEZ-CRUZ, M. \& MARTÍNEZ-PACHECO, A.I. 2005. Estructura y densidad de la red de caminos en la Reserva de la Biosfera Mariposa Monarca. Investigaciones Geográficas. Boletín del Instituto de Geografia, UNAM. 57: 68-80.

REIJNEN, R. \& FOPPEN, R. 1994. The effects of car traffic on breeding bird populations in woodland. 1. Evidence of reduced habitat quality for willow warblers (Phylloscopus trochilus) breeding close to a highway. Journal of Applyed. Ecology, 31: 85-94.

RENDÓN, A. \& POLACO, O.J. 1996. Mortalidad en carreteras de la tortuga del desierto Gopherus berlandieri. Boletín de la Sociedad Herpetológica Mexicana, 7(1): 11-12.

RZEDOWSKI, J. 1978. Vegetación de México. LIMUSA, México. 432p.

SÁNCHEZ-COLÓN, S.; ARTURO, M.; CRUZ-LEYVA, I. \& VELÁZQUEZ, A. 2008. Estado y transformación de los ecosistemas terrestres por causas humanas. Pp. 75-129. In: R. Dirzo, R. González \& I. March (eds.), Capital natural de México, Vol. II: Estado de conservación y tendencias de cambio. Comisión Nacional para el Conocimiento y Uso de la Biodiversidad, México. 809p.

SCME (Sociedad Científica Mexicana de Ecología A. C.). 2013. IV Congreso Mexicano de Ecología: Conocimiento Ecológico para la Solución de Problemas Ambientales. 2013. S9 Impacto ambiental de las carreteras. Miércoles 20 de marzo de 2013, Villahermosa Tabasco México. 7 pláticas. http://www.archivos.
ujat.mx/2012/div_dacbiol/ecologia/Programa \%20General\%20 IV\%20Congreso $\% 20$ Mexicano $\% 20 \mathrm{de} \% 20$ Ecologia $\% 2012 \% 20$ Marzo.pdf

SCT (Secretaría de Comunicaciones y Transporte). 1997. Manual de procedimientos para el aprovechamiento del derecho de vía en caminos y puentes de cuota. Subsecretaria de infraestructura Unidad de autopistas de cuota. Instituto Mexicano del Transporte, Distrito Federal, México. 38p.

SCT (Secretaría de Comunicaciones y Transporte). 2007. Programa Nacional de Infraestructura 2007-2012 Sector de Comunicaciones y Transporte 2007. Instituto Mexicano del Transporte, Distrito Federal, México. 50p.

SCT (Secretaría de Comunicaciones y Transporte) \& IMT (Instituto Mexicano del Transporte). 2009. Manual Estadístico del Sector Transporte 2009. Sanfandila, Qro. 330p. http://www. imt.mx/archivos/Publicaciones/Manual/mn2009.pdf

SCT (Secretaría de Comunicaciones y Transporte) \& IMT (Instituto Mexicano del Transporte). . 2010. Manual Estadístico del Sector Transporte 2010. Sanfandila, Qro. 333p. http://www. imt.mx/archivos/Publicaciones/Manual/mn2010.pdf

SCT (Secretaría de Comunicaciones y Transporte); BIIA (Biología Integral e Impacto Ambiental); EASAC (Ecología Aplicada del Sureste A.C); Universidad Autónoma de Campeche \& Universidad de Calgary. 2011. Cine minuto Volcán de los Murciélagos Calakmul. <http://www.youtube.com/ watch?v=vHThGIvj80M $>($ Accessed 17/02/2012).

SEILER. A. 2001. Ecological Effects of Roads: A review. Department of Conservation Biology SLU Uppsala Swedish. Introductory Research Essay, 9: 1-40. http://idd00s4z.eresmas. net/doc/transp/ecoeffectsonroads.pdf

SEMARNAT (Secretaría de Medio Ambiente y Recursos Naturales). 2012. Guía para la presentación de la manifestación de impacto ambiental del sector vías generales de Comunicación Modalidad: Particular. Secretaría de Comunicaciones y Transporte (SCT), Distrito Federal, México. 117p.

SUNYER-MARTÍN，P. 2011. Tendencias de la Geografía Histórica en México. Revista Bibliográfica de Geografía y Ciencias Sociales, 16(922). <http://www.ub.edu/geocrit/b3w922.htm>

VAN DER REE, R.; JAEGER, J.A.G.; VAN DER GRIFT, E.A. \& CLEVENGER., A.P. 2011. Effects of roads and traffic on wildlife populations and landscape function: road ecology is moving towards larger scales. Ecology and Society, 16(1): 48. <http:// www.ecologyandsociety.org/vol16/iss1/art48/> 
WATKINS, R.Z.; CHEN, J.; PICKENS, J. \& BROSOFSKE K, D.

2003. Effects of Forest Roads on Understory Plants in a Managed

Hardwood Landscape. Conservation Biology, 17(2): 411-419, http://dx.doi.org/10.1046/j.1523-1739.2003.01285.x

Submetido em 26/06/2012

Aceito em 10/03/2013 